\title{
Experimental Infection of Lambs with an Equine Granulocytic Ehrlichia Species Resembling the Agent that Causes Human Granulocytic Ehrlichiosis (HGE)
}

\author{
By S. Stuen ${ }^{1}, K$. Artursson $^{2}$ and E. Olsson Engvall ${ }^{2}$ \\ ${ }^{1}$ Department of Sheep and Goat Research, Norwegian College of Veterinary Medicine, Sandnes, Norway, and \\ ${ }^{2}$ National Veterınary Institute, Uppsala, Sweden.
}

\begin{abstract}
Stuen S, Artursson K, Olsson Engvall E: Experimental infection of lambs with an equine granulocytic Ehrlichia species resembling the agent that causes human granulocytic ehrlichiosis (HGE). Acta vet. scand. 1998, 39, 491-497. - Five lambs were inoculated with a granulocytic Ehrlichıa species onginally isolated from a Swedish horse with granulocytic ehrlichiosis (EGE). The 16S rRNA gene sequence of the Swedish Ehrlichia sp causing EGE was identical to the sequence of the agent causing human granulocytic ehrlıchiosis (HGE). After the inoculation, infected neutrophils and a low serologic response were seen in all lambs, but no clinical symptoms were observed. In one lamb $17 \%$ of the neutrophils were infected without a corresponding fever. Six weeks later the lambs were inoculated with an ovine isolate of $E$. phagocytophila After challenge with $E$. phagocytophila the lambs reacted with fever and infected granulocytes. The results presented herein show that the equine Ehrlichia 1solate was infective for lambs but generated weak immune response and no distinctive protection from subsequent challenge with $E$. phagocytophila.
\end{abstract}

E. phagocytophila; antibodies; immunity.

\section{Introduction}

Tick-borne fever (TBF) in ruminants caused by Ehrlichia phagocytophila was first described in sheep (MacLeod 1932), and later in goats (MacLeod \& Gordon 1933) and cattle (Hudson 1950). Granulocytic ehrlichiosis caused by Ehrlichia equi has so far only been reported from horses in USA (Madigan 1993), but similar granulocytic Ehrlichia-infection in horses has been described from Germany (Büscher et al. 1984), Switzerland (Herman et al. 1985), Sweden (Bjöersdorff et al. 1990), United Kingdom (Korbutiak \& Schneiders 1994) and Denmark (Eriksen et al. 1997).

New strains of granulocytic Ehrlichia have recently been characterised, such as the agent causing human granulocytic ehrlichiosis (HGE) (Chen et al. 1994), and an unnamed Ehrlichia species isolated from dogs and horses in Sweden (Johansson et al. 1995) and from dogs and horses in USA (Greig et al. 1996, Madigan et al. 1996). The Ehrlichia isolates from both horses and dogs in Sweden are identical with respect to the $16 \mathrm{~S}$ rRNA nucleotide sequence to the agent that causes HGE ( $\mathrm{Jo}$ hansson et al. 1995), while it differs in only 2 and 3 positions from the 16S rRNA sequences of $E$. phagocytophila and E. equi, respectively (Olsson Engvall et al. 1996).

Ehrlichia spp. seem to have a preference for certain mammalian species in nature (Rikihisa 
1991), although experimental infections have shown that it is possible to transmit granulocytic Ehrlichia spp. between different animal hosts. Thus, E. equi has been experimentally transmitted from horses to donkeys, sheep, goats, macaques, baboons and dogs (Gribble 1969, Lewis et al. 1975), and E. phagocytophila has been transmitted from sheep to splenectomızed mice and guinea pigs (Foggie \& Hood 1961) and reindeer (Stuen 1996). Furthermore, the HGE-agent has been transmitted from humans to horses (Madigan et al. 1995) and mice (Telford et al. 1996). Serological evidence of a granulocytic Ehrlichia infection in humans has recently been obtained in both Norway and Sweden (Bakken et al. 1996, Dumler et al 1997).

Observations on the immunity to TBF indicate that the immune response varies according to the strain of the organism, the type and age of the host and the time and frequency of challenge (Woldehiwet \& Scott 1993). The aim of the present study was to examine whether an Ehrlichia species causing equine granulocytic ehrlıchiosis (EGE) could infect lambs and induce immunity to TBF.

\section{Materials and methods}

Seven 6 months old lambs of the Dala and Rygja breeds were used. Five lambs were inoculated intravenously on day 0 with $5 \mathrm{ml}$ of nonstabilated blood from a Swedish horse, known to be infected with a granulocytic Ehrlichia sp. (Olsson Engvall et al. 1996). The blood had been kept frozen at $-70^{\circ} \mathrm{C}$ and was thawed immediately before use. Two of the lambs inoculated with Ehrlichia were given prednisolone (Prednisolon ${ }^{\circledR}$, Leo, Denmark) intramuscularly, $50 \mathrm{mg}$ daily on days $-2,-1,0$ and 1 , respectively. Two lambs served as controls and received $5 \mathrm{ml}$ of a defrosted non-Ehrlichia infected horse blood. All anımals were kept indoors from birth and during the whole experimental period.
EDTA-blood samples were collected on days 0, $2,4,6,8,10,12,13,14,16,18,21,25,28,35$, $42,45-52,54,56,58,60$ and 63. Hematological values, including total and differential leucocyte counts, were carried out electronically (Technicon $\mathrm{H} 1{ }^{\circledR}$, Miles Inc., USA) and blood smears were prepared and stained with MayGrünwald Giemsa. Four hundred neutrophils were microscopically examined on each smear and the number of cells containing inclusions was recorded. The percentage of parasitised neutrophilic granulocytes was calculated. Rectal temperatures were measured once daily at the same hour in the morning. The incubation period was defined as the period between inoculation and the first day of fever $\left(\geq 40.0^{\circ} \mathrm{C}\right)$. The duration of fever was recorded as the number of days with body temperature of $40.0^{\circ} \mathrm{C}$ or more. The magnitude of fever was calculated as the area under the temperature curve for each lamb as described by Woldehiwet \& Scott (1982). All lambs were weighed weekly during the whole experımental period. To investigate if the Ehrlichia infected lambs had become immune to TBF, all lambs were inoculated intravenously with $1 \mathrm{ml}$ of a whole blood dimethyl sulphoxide stabilate of an ovine $E$. phagocytophila strain, which had been stored at $-70^{\circ} \mathrm{C}$, on day 42 (Stuen et al 1992). Clinical and hematological changes were observed in these lambs for the next 3 weeks.

Serum samples were collected from the lambs on days $0,7,14,21,28,42,49,56$ and 66 . An indirect immunofluorescence antibody assay (IFA) was used to determine antibodies to $E$ equi (Protatek International and Organon Teknika) (Madigan et al. 1990, Artursson et al. submitted).

\section{Results}

No fever $\left(\geq 40^{\circ} \mathrm{C}\right)$ or other signs of illness were observed in the lambs durıng the first 42 days after inoculation. However, a variable percent- 
Table 1. Percentage of infected cells in lambs inoculated with an Ehrlichia species originally isolated from a horse. The percentage was determıned by examinıng 400 neutrophıls in a May-Grünwald Giemsa staıned blood smear.

\begin{tabular}{cccccccccccccc}
\hline \multirow{2}{*}{$\begin{array}{c}\text { Lamb } \\
\text { no }\end{array}$} & 0 & 2 & 4 & 6 & 8 & 10 & 12 & 14 & 16 & 18 & 21 & 25 \\
\cline { 2 - 11 } & & - & - & - & - & - & - & - & 0.25 & - & - & - & - \\
1 & - & - & - & - & - & - & - & 0.25 & 175 & - & 025 & - \\
2 & - & - & - & - & 0.25 & 05 & 175 & 15 & 05 & - & - & - \\
3 & - & - & 25 & - & 0.25 & 2.5 & 6.75 & 6.0 & 0.25 & - & - & - & - \\
4 & - & 025 & - & 05 & 13.5 & 17.0 & 5.75 & - & - & 0.25 & - & - \\
5 & - & - & - & - & - & - & - & - & - & - & - & - & - \\
6 & - & - & - & - & - & - & - & - & - & - & - & - & - \\
7 & - & - & - & - & - & - & -
\end{tabular}

Lambs 1-5 were infected with Ehrlichia sp on day 0

Lambs 4 and 5 were given $50 \mathrm{mg}$ prednisolone $1 \mathrm{~m}$. on days $-2,-1,0$ and 1 .

Lambs 6 and 7 were uninfected controls

- no inclusions were found.

age of infected neutrophils was registered in the blood of all lambs inoculated with the equine Ehrlichia isolate (Table 1). The absolute number of infected cells varied from $3.4 \times 10^{6}$ to $340 \times 10^{6}$ infected neutrophils/1, while the corresponding percentage of infected cells varied from 0.25 to 17.0 , respectively. The 2 lambs given prednisolone had the highest number of infected granulocytes and showed a decrease in the blood neutrophil level on day 12 and day 14, respectively, but neutropenia (i.e. no. of neutrophils $<0.7 \mathrm{G} / 1$ ) was not observed (data not shown). No other hematological reaction was registered durıng this period.

After inoculation with E. phagocytophila on day 42 all lambs reacted with fever and infected neutrophils (Tables 2 and 3). The lambs also showed dullness, inappetence and coughing, which lasted for 3 to 4 days.

No difference in weight gain between the lambs was observed during the first 42 days of the experimental period. However one week after inoculation with $E$. phagocytophila, the mean weight dropped $1.6( \pm 1.02) \mathrm{kg}$ in the animals previously infected with the equine isolate and $3.5( \pm 1.50) \mathrm{kg}$ in the lambs not infected previ- ously. Seven days later the lambs had gained weight again, 2.6 and $2.0 \mathrm{~kg}$ (mean values) in these 2 groups, respectively (data not shown).

After the first Ehrlichia sp. infection 2 of the lambs developed a positive antibody titre to $E$. equi (Table 4). After the inoculation with $E$. phagocytophila on day 42, positive fluorescent antibody titres to $E$. equi were found within 14 days in all lambs.

\section{Discussion}

The present study shows that the lambs only acquired a subclinical infection when inoculated with an equine granulocytic Ehrlichia sp. 1solate. In spite of the lack of clinical signs, infected neutrophils were detected in the blood of all inoculated lambs. This is in accordance with an earlier experimental $E$. equi infection in sheep, where the sheep were afebrile after inoculation with infected horse blood, but inclusions were seen in granulocytes of some of the animals (Stannard et al. 1969). Similarly, horses do not seem to be susceptible to an $E$. phagocytophila infection, since no clinical signs, granulocytic inclusions or serologic responses were observed after infection with an 
Table 2. Means ( \pm SD) of different clinıcal variables in lambs challenged with Ehrlichia phagocytophila 42 days after being inoculated with an Ehrlichia sp. originally isolated from a horse

\begin{tabular}{lccc}
\hline & \multicolumn{3}{c}{ Infected with Ehrlichla sp } \\
\cline { 2 - 4 } & \multicolumn{1}{c}{ Infected $(\mathrm{n}=5)$} & Uninfected $(\mathrm{n}=2)$ \\
\hline Incubation period (days) & $5.0 \pm 0$ & 4.0 \\
Maximum temperature $\left({ }^{\circ} \mathrm{C}\right)$ & $41.4 \pm 0.16$ & 41.8 \\
Duration of fever (days) & $48 \pm 2.71$ & 85 \\
Magnitude of fever $\left(\mathrm{mm}^{2}\right)^{*}$ & $336 \quad \pm 113.8$ & 564 \\
Minimum of neutropenia (G/1) & $0.40 \pm 006$ & 0.41 \\
Duration of neutropenia (days) & $6.8 \pm 1.92$ & 7.0 \\
\hline
\end{tabular}

* The magnitude of fever is calculated as the area uner the temperature curve with $40^{\circ} \mathrm{C}$ as base line

Table 3. Percentage (mean $\pm \mathrm{SD}$ ) of infected neutrophils in lambs challenged with $E$ phagocytophila 42 days after inoculation with an Ehrlichia sp. onginally isolated from a horse. No inclusions were observed before day 4 .

\begin{tabular}{lrrrrrrrrr}
\hline Infected with & \multicolumn{8}{c}{ Days post inoculation with $E$ phagocytophlla } \\
\cline { 2 - 10 } Ehrlchia sp & \multicolumn{1}{c}{5} & \multicolumn{1}{c}{5} & \multicolumn{1}{c}{7} & 8 & 9 & 10 & 12 & 14 \\
\hline Infected (5 lambs) & 12.4 & 47.8 & 33.2 & 26.9 & 19.1 & 13.6 & 2.6 & $<1$ & $<1$ \\
& \pm 6.6 & \pm 5.4 & \pm 10.2 & \pm 7.8 & \pm 7.4 & \pm 5.0 & \pm 2.7 & & \\
Uninfected (2 lambs) & 19.5 & 54.5 & 41.3 & 43.8 & 46.0 & 275 & 30 & 20 & $<1$ \\
\hline
\end{tabular}

Table 4. Reciprocal antibody titres to $E$. equ in lambs inoculated with an equine Ehrlichia sp. on day 0 and challenged with $E$ phagocytophlla on day 42 . A titre less than 40 was considered negative

\begin{tabular}{|c|c|c|c|c|c|c|c|c|}
\hline \multirow{2}{*}{$\begin{array}{l}\text { Lamb } \\
\text { no }\end{array}$} & \multicolumn{8}{|c|}{ Days after inoculation } \\
\hline & 0 & 14 & 21 & 28 & 42 & 49 & 56 & 66 \\
\hline 1 & - & - & - & - & - & 80 & 5120 & 2560 \\
\hline 2 & - & - & - & - & - & 80 & 10240 & 5120 \\
\hline 3 & - & - & - & 80 & 40 & - & 160 & 160 \\
\hline 4 & - & - & - & - & - & - & 640 & 320 \\
\hline 5 & - & - & - & - & 320 & 320 & 1280 & 640 \\
\hline 6 & - & - & - & - & - & - & 640 & 640 \\
\hline 7 & - & - & - & - & - & - & 320 & 320 \\
\hline
\end{tabular}

Lambs 1-5 were infected with Ehrlichia sp. on day 0 and with $E$ phagocytophila on day 42.

Lambs 4 and 5 were given $50 \mathrm{mg}$ prednisolone 1.m. on days $-2,-1,0$ and 1 .

Lambs 6 and 7 were only infected with $E$ phagocytophila on day 42 .

- titre $<40$.

ovine strain of E. phagocytophila (Stuen et al. 1995).

The percentage of infected cells in the 2 lambs that were given prednisolone was more than 3 times higher than in the untreated lambs. The difference in the number of infected neutrophils could be due to a drug-induced immunosuppression in the lambs given prednisolone, mak- 
ing them more susceptible to the infection ( $T i$ zard 1992). Immunosuppressive drugs have earlier been reported to induce relapsis in TBFinfected sheep (Scott 1978). These 2 lambs also showed a drop in the neutrophil level at the end of the bacteriemic period. However, a neutropenia, which is typical for a TBF infection in lambs, was not observed. No hematologic changes were observed in the other infected lambs during the same period.

After challenge with E. phagocytophila the lambs reacted with fever and infected granulocytes as described earlier in TBF-infected lambs (Woldehiwet \& Scott 1993). The results indicate a difference between the 2 groups of lambs in the length of the incubation period, the temperature reaction, the weight loss and in the level of bacteriemia (Tables $2 \& 3$ ), suggesting some cross-protection between the ehrlichiae causing EGE and TBF. However, statistical calculations on the differences were not carried out due to the low number of controls. In another study it was shown that one horse, first experimentally infected with HGE agent, became resistant to a subsequent challenge with $E$. equi (Barlough et al. 1995).

In the present study no or a very low serologic response was observed during the primary infection, indicating a low antigenic stimulation of the immune system. One reason for this low antibody response could be that $E$. equi was used as antigen in the IFA test. Serological cross-reactions between $E$. equi, E. phagocytophila and the agent causing HGE have been reported, but the titre to a heterologous strain of Ehrlichia was normally lower than to the homologous strain (Dumler et al. 1995, Nicholson et al. 1997). Unfortunately, no antigen slides with E. phagocytophila or the Swedish Ehrlichia species were available for testing the sera in this study.

The low serologic antibody titre could also have been due to a low immunogenicity in sheep to the equine Ehrlichia isolate used. In contrast, the same agent could cause serious infections and give high IFA titres to $E$. equi when inoculated into dogs (Egenvall et al. 1998) and horses (Olsson Engvall unpublished observations).

When challenged with E. phagocytophila, the lambs in the present study showed an antibody response within 14 days. Except for 2 lambs which reacted with a high antibody titre, a moderat increase in the titre was registered. Again this could be due to the use of $E$. equi as antigen in the fluorescent test (Stuen et al. 1998).

Earlier studies of experimental infection with different isolates of $E$. phagocytophila have shown a variable degree of clinical manifestations and cross-immunity (Foggie 1951, Tuomi 1967a,b, Scott 1984). This could be due to variations in the genes coding for surface proteins (Sumner et al. 1997). Hopefully, more genetic information which will explain differences in the pathogenicity between isolates of granulocytic ehrlichiae infecting sheep, will be available in the near future. It is still a question if $E$. equi, E. phagocytophila and the agent that causes HGE, should be considered as separate species, subspecies, or different variants of one species. Both 16S rRNA and groESL sequence data indicate that these agents are very closely related (Chen et al. 1994, Sumner et al. 1997). Molecular characteristics such as DNA-DNA reassociation experiments have to be performed for a definite classification of these ehrlichiae, but also biological and ecological differences, e.g. host competence, between Ehrlichia isolates should be considered (Dumler et al. 1995, Olsson Engvall et al. 1996).

\section{Acknowledgement}

The authors want to thank Ulla-Britt Wikstrøm for excellent technical assistance. 


\section{References}

Artursson K, Gunnarsson A, Wikstrøm U-B, Olsson Engvall $E$ A serological and clinical follow-up in horses with confirmed equine granulocytic ehrliciosis (submitted for publication)

Bakken JS, Krueth J, Tilden RL, Dumler JS, Kristiansen $B E$ Serological evidence of human granulocytic ehrlichiosis in Norway. Eur. J. clin Microbiol. Infect. Dis. 1996, 15, 829-832.

Barlough JE, Madigan JE, DeRock E, Dumler JS, Bakken JS Protection against Ehrlichia equi is conferred by prior infection with the human granulocytotropic ehrlıchia (HGE agent). J clin Microbiol. 1995, 33, 3333-3334.

Bjöersdorff A, Christenson D, Johnsson A, Sjöstrom $A C$, Madigan $J E$ Ehrlıchia equi-infektion diagnostıserat hos hảst (Granulocytic ehrlıchıosis in the horse - the first verified case in Sweden) Svensk Vet -Tidn. 1990, 42, 357-360.

Büscher G, Gandras R, Apel G, Friedhoff KT Der erste Fall von Ehrlichiose beim Pferd in Deutschland (Kurzmittellung). (The first case of ehrl1chiosis in a horse in Germany). Dtsch tierarztl Wschr. 1984, 91, 408-409

Chen, S-M, Dumler JS, Bakken JS, Walker DH Identıfication of a granulocytotropic Ehrlichia species as the etiologic agent of human disease J. clin Microbiol. 1994, 32, 589-595.

Dumler JS, Asanovich KM, Bakken JS, Rıchter P, Kimsey R, Madigan JE Serologic cross-reactıons among Ehrlichia equi, Ehrlichia phagocytophila, and human granulocytic ehrlichia. J. clin Microbiol 1995, 33, 1098-1103

Dumler JS, Dotevall L, Gustafson R, Granstrom M A population-based seroepidemiologic study of human granulocytic ehrlıchiosis and Lyme borreliosis on the west coast of Sweden J. infect Dis. 1997, 175, 720-722

Egenvall AE, BJöersdorff AI, Lilliehöok I, Olsson Engvall E, Karlstam E, Artursson K, Hedhammar A, Gunnarsson A Early manifestations of granulocytic ehrlichiosis in dogs inoculated experimentally with a Swedish Ehrlichia species isolate. Vet. Rec 1998, 143, 412-417.

Eriksen L, Hansen JF, Abıldtrup E, Olsson Engvall $E$ Granulocytær ehrlichiose hos hest påvist 1 Danmark. (Equine granulocytic ehrlıchiosis diagnosed in Denmark) Dansk Vet.-T 1997, 80, 231-234.

Foggie $A$ Studies on the infectious agent of tickborne fever in sheep. J. Path Bact. 1951, 63, 1-15.
Foggle A, Hood CS Adaptation of the infectious agent of tıck-borne fever to guinea-pigs and mice. J. comp Path 1961, 71, 414-427.

Gretg B, Asanovich KM, Armstrong PJ, Dumler JS Geographic, clinical, serologic, and molecular evidence of granulocytic ehrlichiosis, a likely zoonotic disease, in Minnesota and Wisconsin dogs. J. clın. Microbiol 1996, 34, 44-48.

Gribble DH Equine ehrlichiosis J Amer. vet med. Ass 1969, 155, 462-469

Hermann M, Baumann D, Lutz H, Wild P Erster d1agnostızierter Fall von equiner Ehrlichiosis in der Schweiz (The first diagnosed case of equine ehrlichiosis in Switzerland) Pferdeheilkd 1985, 1, 247-250

Hudson JR The recognition of tick-borne fever as a disease of cattle Brit. vet. J. 1950, 106, 3-17.

Johansson K-E, Pettersson B, Uhlén M, Gunnarsson A, Malmquist $M$, Olsson $E$ Identification of the causative agent of granulocytic ehrlichiosis in Swedish dogs and horses by direct solid phase sequencing of PCR products from the 16S rRNA gene Res. vet Sc1 1995, 58, 109-112

Korbutıak E, Schneiders DH First confirmed case of equine ehrlichiosis in Great Britain Equine vet. Educ 1994, 6, 303-304

Lewls GE, Huxsoll DL, Ristic M, Johnson AJ Experimentally induced infection of dogs, cats and nonhuman primates with Ehrlichia equi, etiologic agent of equine ehrlichiosis Amer J vet Res $1975,36,85-88$

MacLeod $J$ Preliminary studies in the tick transmission of louping 1ll. II A study of the reaction of sheep to tick infestation Vet J 1932, 88, 276284

MacLeod J, Gordon WS Studies in tick-borne fever of sheep 1 Transmission by the tick, Ixodes riclnus, with a description of the disease produced Parasitology 1933, 25, 273-283.

Madigan JE, Hietala S, Chalmers S, DeRock E Seroepidemiologic survey of antibodies to Ehrlichia equi in horses of northern Calıfornia. J Amer. vet. med Ass 1990, 196, 1962-1964.

Madıgan JE Equine ehrlichiosis In. Woldehiwet Z, Ristic M (eds ). Rickettsial and chlamydial diseases of domestic anımals Pergamon Press, Oxford, 1993, 209-214.

Madigan JE, Richter PJ, Kimsey RB, Barlough JE, Bakken JS, Dumler JS Transmission and passage in horses of the agent of human granulocytic ehrlichiosis J infect. Dis 1995, 172, 1141-1144

Madigan JE, Barlough JE, Dumler JS, Schankman 
NS, DeRock E: Equine granulocytıc ehrlıchıosis in Connecticut caused by an agent resembling the human granulocytotropic ehrlichia. J. clin. Microbiol 1996, 34, 434-435.

Nicholson WL, Comer JA, Sumner JW, GingrichBaker C, Coughlin RT, Magnarelli LA, Olson JG, Childs JE An indirect immunofluorescence assay using a cell culture-derived antigen for detection of antibodies to the agent of human granulocytıc ehrlichıosıs. J. clin. Microbiol. 1997, 35 , 1510-1516

Olsson Engvall E, Pettersson B, Persson M, Artursson $K$, Johansson $K-E$ A $16 \mathrm{~S}$ rRNA-based PCR assay for detection and identification of granulocytic Ehrlichıa species in dogs, horses and cattle. J clin. Microbiol. 1996, 34, 2170-2174.

Rikıhısa $Y$. The tribe Ehrlıchieae and ehrlichial diseases. Clin. Microbiol. Rev. 1991, 4, 286-308

Scott GR Annual report, Centre of Tropical Veterinary Medicıne, Edınburgh, 1978, 20.

Scott GR. Annual report, Centre of Tropical Veter1nary Medicine, Edinburgh, 1984, 21.

Stannard AA, Gribble DH, Smith RS Equine ehrl1chiosis: A disease with similarities to tick-borne fever and bovine petechial fever Vet Rec. 1969, 84, 149-150.

Stuen $S$, Hardeng F, Larsen HJ. Resistance to tickborne fever in young lambs. Res. vet. Sc1. 1992, 52, 211-216

Stuen S, Grønstøl H, Larsen HJS. Experimental inoculation of horses with Ehrlichia phagocytophila In Proceedings. The Second International Conference on Tick-borne Pathogens at the Host-Vector Interface. Kruger Natıonal Park, South Africa 1995, 240-243

Stuen $S$ Experımental tick-borne fever infection in reindeer (Ranglfer tarandus tarandus) Vet. Rec. 1996, 138, 595-596.

Stuen $S$, Olsson Engvall E, Artursson $K$. The persistence of Ehrlichia phagocytophila infection in lambs in relation to clinical parameters and ant1body responses Vet. Rec 1998, 143 In press

Sumner JW, Nicholson WL, Massung RF PCR amplification and comparison of nucleotıde se- quences from the groESL heat shock operon of Ehrlichia species. J clın. Microbiol. 1997, 35, 2087-2092.

Telford SR, III, Dawson JE, Katavolos P, Warner CK, Kolbert CP, Persing DH Perpetuation of the agent of human granulocytic ehrlichiosis in a deer tıck-rodent cycle. Proc. natl Acad. Sc1. USA, 1996, 93, 6209-6214.

Tizard I Veterınary immunology. 4th edition, WB Saunders Company, Philadelphia, 1992.

Tuomı $J$ Experımental studies on bovine tick-borne fever. 2. Differences in virulence of strains in cattle and sheep. Acta path microbiol scand. 1967a, 70, 577-589.

Tuomı $J \cdot$ Experimental studies on bovine tick-borne fever. 3 Immunological strain differences. Acta path. microbiol. scand. 1967b, 71, 89-100.

Woldehiwet $Z$, Scott $G$ Immunological studies on tıck-borne fever in sheep J. comp. Path. 1982 , 92, 457-467.

Woldehiwet Z, Scott GR - Tick-borne (pasture) fever. In. Woldehiwet Z., Ristıc M. (eds ): Rickettsıal and chlamydial diseases of domestic animals Pergamon Press, Oxford, 1993: 233-254

\section{Sammendrag}

Eksperimentell infeksjon av lam med en equin granulocyttcer Ehrlichia sp som ligner på det agens som forårsaker human granulocyttor ehrlichiose (HGE)

Fem lam ble podet med en granulocyttær Ehrlichıa sp opprinnelig isolert fra en svensk hest med granulocyttær ehrlıchiose (EGE) Etter podıngen ble parasittemı og en lav serologisk respons påvist hos lamma, men ingen klınıske symptomer ble registrert Hos et lam var $17 \%$ av de nøytrofile infisert uten at feber ble observert Seks uker senere ble lamma podet med en ovin stamme av $E$ phagocytophila $\mathrm{Re}$ sultatet fra denne undersøkelsen viste at det equine Ehrlıchıa isolatet var infektıvt for lam, men forårsaket en svak immunrespons og ga ingen reell beskyttelse mot en senere $E$ phagocytophila infeksjon

(Recelved November 22, 1997; accepted September 10, 1998).

Reprints may be obtained from: S. Stuen, Department of Sheep and Goat Research, Norwegian College of Veterınary Medıcine, Kyrkjev, 332/334. N-4300 Sandnes, Norway. E-ma1l· snorre stuen@veths.no, tel: +47 51603510, fax: +4751627290 . 
